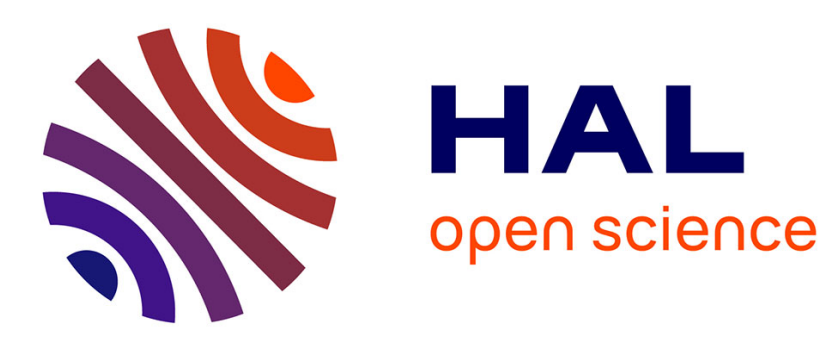

\title{
Statistical analysis of rockfall volume distributions: implications for rockfall dynamics.
}

C. Dussauge, Jean-Robert Grasso, Agnès Helmstetter

\section{To cite this version:}

C. Dussauge, Jean-Robert Grasso, Agnès Helmstetter. Statistical analysis of rockfall volume distributions: implications for rockfall dynamics.. Journal of Geophysical Research: Solid Earth, 2003, 108 (B6), pp.2286. 10.1029/2001JB000650 . hal-00109913

\section{HAL Id: hal-00109913 \\ https://hal.science/hal-00109913}

Submitted on 6 Dec 2007

HAL is a multi-disciplinary open access archive for the deposit and dissemination of scientific research documents, whether they are published or not. The documents may come from teaching and research institutions in France or abroad, or from public or private research centers.
L'archive ouverte pluridisciplinaire HAL, est destinée au dépôt et à la diffusion de documents scientifiques de niveau recherche, publiés ou non, émanant des établissements d'enseignement et de recherche français ou étrangers, des laboratoires publics ou privés. 


\title{
Statistical Analysis of Rock Fall Volume Distributions: Implications for Rock Fall Dynamics
}

\author{
Carine Dussauge \\ Laboratoire Interdisciplinaire de Géologie et de Mécanique, Université Joseph Fourier, France
}

Jean-Robert Grasso

Laboratoire de Géophysique Interne et Tectonophysique, Observatoire de Grenoble, Université Joseph Fourier, France

Agnès Helmstetter

Laboratoire de Géophysique Interne et Tectonophysique, Observatoire de Grenoble, Université Joseph Fourier, France

\begin{abstract}
We analyse the volume distribution of natural rock falls on different geological settings, i.e., calcareous cliffs in the French Alps, Grenoble area, and granite Yosemite cliffs, California sierra, and different volume ranges, i.e., regional and world wide catalogs. Contrary to previous studies that included several types of landslides, we restrict our analysis to rock fall sources which originated on sub vertical cliffs. For the three data sets, we find that the rock fall volumes follow a power law distribution with a similar exponent value, within error bars. This power-law distribution was also proposed for rock fall volumes that occurred along road cuts. All these results argue for a recurrent power law distribution of rock fall volumes on sub vertical cliffs, for a large range of rock fall sizes $\left(10^{2}-10^{10} \mathrm{~m}^{3}\right)$, regardless of the geological settings and of the pre- existing geometry of fracture patterns that are drastically different on the three studied areas. The power law distribution for rock fall volumes could emerge from two types of processes. First, the observed power law distribution of rock fall volumes is similar to the one reported for both fragmentation experiments and fragmentation models. This argues for the geometry of rock mass fragment sizes to possibly control the rock fall volumes. This way neither cascade nor avalanche processes would influence the rock fall volume distribution. Second, without any requirement of scale invariant quenched heterogeneity patterns, the rock mass dynamics can arise from avalanche processes driven by fluctuations of the rock mass properties, e.g. cohesion or friction angle. This model may also explain the power-law distribution reported for landslides involving unconsolidated materials. We find that the exponent values of rock fall volume on sub vertical cliffs, $0.5 \pm 0.2$, is significantly smaller than the $1.2 \pm 0.3$ value reported for mixed landslide types. This change of exponents can be driven by the material strength, that controls the in-situ topographic slope values, as simulated in numerical models of landslides [Densmore et al., 1998; Champel et al., 2002].
\end{abstract}




\section{Introduction}

Rock falls, rockslides and rock avalanches are defined as rapid movements of rocks driven by global gravity forces, having their origin on steep rock slopes, including sub vertical cliffs. These phenomena are a subset of the more general landslide phenomena, which can include falls, slumps and slides in all kind of ground material from stiff rock mass to unconsolidated or poorly cemented materials [Varnes, 1978; Keefer, 1999]. The word rock fall is usually used to describe small phenomena, ranging in size from block falls of a few $\mathrm{dm}^{3}$ up to $10^{4} \mathrm{~m}^{3}$ events. Rockslides sometimes involve more than $10^{5} \mathrm{~m}^{3}$ and rock avalanches can reach several million cubic meters [Varnes, 1978; Keefer, 1984; 1999]. In this study we will use the rock fall label without any volume distinction, nor distinction in the failure mechanism.

As for floods, earthquakes or volcanic eruptions, evaluating rock fall dynamics means analysing the location, size and time patterns of rock fall events. Here we focus on the distribution of rock fall volumes. For some natural phenomena, including floods and earthquakes, statistical analysis are used to derive the recurrence rate of an event of a given size. The flood sizes are proposed to follow an exponential distribution [e.g.Guillot and Duband, 1967; U.S. Water Resources Council, 1982], whereas the earthquake sizes are best fitted by a power law distribution [Gutenberg and Richter, 1949]. On the first hand, the size distribution can be used for hazard assessment, if we hypothesize the distribution to be stationary over time. On the other hand, the type of distribution can provide routes to further investigate the underlying physical processes.

Power law distributions have been suggested to characterize rock fall distributions triggered along road-cuts [Noever, 1993; Hungr et al., 1999], or natural cliffs [Gardner, 1970; Wieczorek et al., 1995]. In this study we analyse the volume distributions of rock falls from natural cliffs, in different geological settings, different volume ranges and different time scales. Contrary to earthquakes, rainfalls, or floods, few if any natural slopes or cliffs are continuously monitored in order to provide the exact time of occurrence, location and size of rock fall events. Due to the lack of instrumental monitoring of rock falls, the available inventories are weak compared to some other natural phenomena, with several possible biases induced by non homogeneous sampling in time, space and size domains. We test how reports of rock fall activity can be used to investigate rock fall volume distribution, the way other scientists used historical catalogs to further constrain contemporary, short time, instrumental catalogs e.g. [Wesnousky et al., $1983 ; 1984]$.

We compare volume distributions of natural rock falls that occurred on Grenoble cliffs, French Alps [RTM, 1996], Yosemite cliffs, Sierra Nevada, California [Wieczorek et al., 1992] and a worldwide inventory of large rockslides [Couture, 1998]. The first two case studies investigate the same temporal scale, about one century, and the same spatial scale, roughly $100 \mathrm{~km}$ of cliff length. The main difference between these 2 case studies is the involved rock masses, layered calcareous cliffs and massive granite rock cliffs, for Grenoble and Yosemite catalogs respectively. For each area, we validate statistically the power law distribution function as an estimate for the observed rock fall volume distribution. Exponent values are similar, within error bars, for the three data sets. This suggests that the distribution law for rock fall volume does not depend on either the geological setting or the scale of observation. These results are similar to analysis of rock falls that occurred along road cuts [Noever, 1993; Hungr et al., 1999]. We show how this distribution law can be used for rock fall hazard assessment, by analysing the validity domains and limits of this approach. We investigate the possible mechanical models that can reproduce this power law distribution of rock fall volumes.

\section{Data}

\subsection{The Grenoble rock fall inventory, French Alps}

The first data set reports rock fall volume that occurred on subvertical cliffs surrounding the urban area of Grenoble city, French Alps [RTM, 1996]. In order to characterize the geological setting of the cliff, we need to identify the forces acting on this system. Such forces are the long term tectonic forces due to plate tectonic dynamics. Intermediate term and short term forces that act on the cliffs are climatic forcing, i.e., glacial unloading, fluvial incision, temperature, rain, snow and winds and earthquake waves, as sorting by increasing time frequency of applied forces. To cast the cliff geological settings, the rate of base level fall (which can be due to any combination of differential rock uplift rate between cliff and valley and fluvial or glacial incision), is the more relevant parameter to characterize the hill slope. Because this parameter is 
not estimated for the cliff we studied, we use a local differential displacement or a local deformation rate as a proxy to characterize the cliff deformation rate.

These Grenoble cliffs are part of the Chartreuse and Vercors subalpine massifs, made of sedimentary rocks from upper Jurassic and lower Cretaceous age (limestone and marls). Initial bedding is folded and faulted due to alpine horizontal compressive stresses, resulting mostly in subvertical fractures across gently inward dipping stratification (Figure 1). The cliffs dimensions are $50 \mathrm{~m}$ to $400 \mathrm{~m}$ in height, $120 \mathrm{~km}$ in length, as cumulative values on two successive rocky walls (Figure 1). The cliffs elevation ranges from 800 $\mathrm{m}$ to $2000 \mathrm{~m}$. For such an altitude, in the French Alps, the climatic conditions correspond to wet springs and falls seasons and frozen conditions in wintertime. The Chartreuse-Vercors massif is suggested to have a weak local deformation rate, i.e., less than a few $\mathrm{mm} / \mathrm{yr}$ either for horizontal or for vertical displacements [Martinod et al., 1996]. These values are differential displacement we used as a proxy of cliff deformation rates. They come from GPS surveys on Chartreuse Vercors sites. The benchmarks are located $10-20 \mathrm{~km}$ apart from each others all above the cliff edges that extend over $70 \mathrm{~km}$ in length in the Grenoble area [Martinod et al., 1996]. Historical and instrumental seismicity rates are low, with a few $\mathrm{M}=4$ earthquakes reported in the area during the last 5 centuries [Fréchet, 1978; Grasso et al., 1992]. There is no report on rock falls possibly triggered by earthquakes. One possible change in loading conditions is the last glacial unloading (Würm, dated $10^{4}$ yrs before present). Unloading the cliff faces from the ice pressure induces a visco-elastic rebound of the cliffs. The phenomena is mechanically not well quantified on the cliffs because of the difficulty to evaluate the long term rheology of the cliff.

Rock fall activity that occurred in the Grenoble calcareous Alps from 1248 to 1995 was reported by the Restauration des Terrains de Montagnes Office $(R T M)$, a forestry office in charge of natural risks in the French Alps, since 1870 [RTM, 1996]. As the RTM office was created in 1870 , the $1870-1890$ period is the threshold between archive reports for rock fall events and the specific survey of mountain slopes. For each event the available data from the Grenoble catalog are (i) the location of the rock fall, (ii) the date of occurrence, (iii) the volume and the induced damages. Most of this information has been reported by forest guards as described in the previous section, with a sampling rate of once every a few weeks. For some roughly estimated volumes, we provide new volume estimates on the basis of in-situ observation and reanalysis of reports. Reported volumes range from $3 \times$ $10^{-2} \mathrm{~m}^{3}$, i.e., typical of a slight damage on a single house, to $5 \times 10^{8} \mathrm{~m}^{3}$. The largest event of this data set is the $1248 \mathrm{Mt}$ Granier rock avalanche, $40 \mathrm{~km}$ north of Grenoble, with a volume of $5 \times 10^{8} \mathrm{~m}^{3}$ [Goguel and Pachoud, 1972].

For this data set, threshold values are estimated by RTM forest guards. They report they never missed a $500 \mathrm{~m}^{3}$ event size, because of it impact on either infrastructures or on forest structures involving forests, meadows, trails, roads, housing [RTM pers. communication]. They induce changes in the cliff pattern (scars, change in color, geometry) as well. Alternatively, they report they missed a large number of small events, which are to small to induce a significant and visible damage. Up to events close to $10 \mathrm{~m}^{3}$, they report they can miss events. We thus assume the Grenoble inventory to be complete for volumes greater than $500 \mathrm{~m}^{3}$. Because of the non-uniform temporal sampling (Figure 2), one large event in 1248 and just a few ones reported in the 17th - 19th centuries period, we select events within the 1935-1995 time window only. This period is a trade off between a minimum number of available events and a period for which the sampling can be considered as uniform. On such a basis, the Grenoble catalog we used involves 87 events.

\subsection{The Yosemite Valley rock fall inventory, California}

The second data set gathers rock falls that occurred in the Yosemite Valley, Sierra Nevada, California [Wieczorek, 1992]. It concerns cliffs of massive granite from Cretaceous age. The total area covers almost $100 \mathrm{~km}$ of cliff length. Cliffs have a maximum height of $1000 \mathrm{~m}$, with a mean value of $300 \mathrm{~m}$, and an elevation ranging from 1000 to $2300 \mathrm{~m}$ (Figure 3). The climatic setting is roughly a dry and warm spring and summer, and cold wet falls and winter. Rock falls result partly from exfoliation and sheeting processes that are induced by the release of pressure of previously buried rocks (Figure 3 ). The resulting sheets tend to be mainly parallel to the topography [Huber, 1987].

This area is part of the Sierra Nevada "block" which is moving with respect to the stable North American plate. Local differential displacement rates deduced from a GPS survey of less than a $\mathrm{mm} / \mathrm{yr}$ if any, is related to San Andreas tectonics plus shear strain associated with Owens Valley and associated 
faults"[Dixon et al., 2000]. The US Sierra uplift rate is less than a $\mathrm{mm} / \mathrm{yr}$, the uplift rate being not resolved by a 5 years GPS survey [Dixon et al., 2000]. Only about, $5 \%$ of the rock falls are reported as triggered by earthquakes [Wieczorek, 1992]. Last glacial unloading corresponds to the end of the Tioga epoch, 15000 years BP at relatively low elevation [Huber, 1987].

The historical Yosemite rock fall inventory reports 395 events in the 1850-1992 period [Wieczorek, 1992]. Most of them are reported by either National Park Rangers or USGS geologists. As for the Grenoble inventory, there are large uncertainties on reported volumes, and a non-uniform sampling of small volume rock falls over time. The sampling rate is globally shorter than one month, observed data being collected in the Superintendent Monthly report. This sampling rate has been much shorter in the last ten years [ Wieczorek, personal communication]. The threshold for the inventory completeness for the small events is not estimated.

There are two classes of volume estimates in the Yosemite inventory. For one class of rock falls, roughly one quarter of the inventory, the reports allow a quantitative estimate of volumes. For the second class, only qualitative estimates are given. Following the same criterion as for the Grenoble catalog, we select events with quantitative volume estimates in the 1915-1992 period (Figure 4). We obtain 101 events, with volumes ranging from 1 to $6 \times 10^{5} \mathrm{~m}^{3}$. Because qualitative volume estimates exist in the inventory for volumes as large as a few thousands cubic meters, this volume catalog is not complete up to large volumes. We will consider this volume inventory as a subset of the genuine volumes of the Yosemite rock fall population, for the 1915-1992 period.

\subsection{A worldwide rock falls inventory}

The last data set we use is a worldwide collection of large rockslides and rock avalanches, as old as the last glacial epoch [Couture, 1998]. Contrary to the two previous data sets of rock falls that occurred within homogeneous geological setting, e.g. calcareous and granite cliffs respectively, Couture [1998] is an overview of the phenomenology of rock avalanches on Earth and other planets. Therefore the geological setting of these events is obviously heterogeneous, and the sampling method just comes out from a bibliographic study.

From the Couture inventory, we selected 142 Earth events. Estimated volumes are provided by historical reports, based on observations of cliff scars and de- posits or on geomorphological patterns for the oldest events. The collection is not supposed to be exhaustive [Couture, 1998]. The sampling is neither uniform in time, recent events being more often reported than older ones, nor in space domain. Also, the sampling is not uniform in size, the largest events being preferentially reported in historical reports. Like the Yosemite inventory, this data set is one subset of the complete worldwide catalog.

\subsection{Measurement techniques for rock fall inventories}

Concerning the study of earthquakes, rainfalls or floods, instrumental monitoring provides direct or indirect estimates of events occurrence in size, time, and space domains. Few instrumental measurements exist for the study of the rock fall activity, especially concerning natural cliffs. One study uses a continuous seismic monitoring to detect rock fall events and to size up rock fall volumes on a single, well defined cliff [Rousseau, 1999]. Rousseau [1999] uses a seismic model to derive the volume of a rock fall event from the amplitude of the recorded seismic signals. Generally, data about rock falls are mainly reported by forest guards or road surveyors without the help of any quantifying tool.

Due to this lack of instrumental monitoring, the rock fall volumes inventories we used suffer several possible biases. First, the sampling in time domain is driven by the visit rate of the field survey observer, this survey being usually part of a forestry or road survey (not specific to rock fall observation). For some events, the field evidences can disappear within the laps time of two visits. For other events, the visit rate can induce a cumulative effect on rock fall volumes estimates, i.e., all the rock falls which occurred at the same place are estimated as one single event at the sampling rate resolution.

Second, in size domain, rock fall events are reported mainly when they induce damages to natural or anthropic entities. Impacts on forest trees, trails, roads and housing are the main criteria to report the occurrence of a rock fall event. Therefore the rock falls which did not induce damages are seldom reported. This induces a censoring effect for the socalled small events. Small volumes are also under sampled because of the screening effect due to man made protective structures, such as rock fences or forests. As a consequence, non-instrumental inventories are obviously incomplete for the small events.

Another possible bias emerges from the inaccuracy 
of volume estimates, which are based on the observation of the volume of deposits, sometimes coupled with the observation of the visible scar on the slope. Error bars for volumes are thus large and difficult to quantify. For large rock fall volumes, i.e., volumes greater than a few hundreds of cubic meters, the volume estimate comes from the area covered with new rock material and its thickness values along the slope. For smaller rock falls the sum of the volumes of the largest blocks is usually used as a volume estimate. When visible, the surface of the cliff scar that is induced by the rock fall is further used, its thickness being more difficult to assess.

\section{Statistical analysis of volume distribution}

For the three data sets, we test which distribution function best describes the rock fall volume data. For each catalog, the selected events correspond to the time window for which the catalog is supposed to be homogeneous in the time domain. Because of the censoring effect, there is an under sampling of small volume events. For the largest observed volumes, with a size comparable to the cliff height, the distribution may be truncated because of finite size effects. Accordingly, we select only rock fall events above a given volume. This minimum volume is a-priori unknown, and will be estimated from the adjustment of distribution laws to the data. First we search which distribution functions may describe our data. Second, using the $\chi^{2}$ criterion, we test if the rock fall volume distribution is consistent with the hypothesized distribution functions.

\subsection{Grenoble inventory}

The observed cumulative distribution for the Grenoble cliffs is evaluated for the 87 rock fall events in the 1935-1995 period (Figure 5). The distribution is almost linear in a log-log plot for volumes larger than $40 \mathrm{~m}^{3}$. For volumes smaller than $40 \mathrm{~m}^{3}$, we observe a downward departure from the linear behavior that is typical of a censoring effect. Accordingly, we test how the observed cumulative volume distribution may be adjusted by a power-law distribution for the 55 events of volume above $40 \mathrm{~m}^{3}$, i. e.,

$$
N(V) \sim V^{-b},
$$

with $V$ the rock fall volume, $N(V)$ the number of events greater than $V$ and $b$ a constant parameter. To estimate the exponent value, $b$-value, we used the maximum likelihood and linear regression methods because there are the two methods classically suggested in the literature [e.g. Pickering et al., 1995]. Maximum likelihood and linear regression estimates are not independent estimates.

Following $[A k i, 1965]$, the maximum likelihood estimate for $b$ is

$$
b=\frac{1}{\ln (10)\left(<\log (V)>-\log \left(V_{0}\right)\right)},
$$

in the case of a pure power law distribution, with a standard deviation determined by,

$$
\sigma=\frac{b}{\sqrt{N_{1}}},
$$

where $V_{0}$ is the minimum volume used in the power law fit, $\langle\log (V)\rangle$ is the average of $\log (V)$ for events larger than $V_{0}$ and $N_{1}$ the number of events with volume larger than $V_{0}$. A more complex equation is necessary when the distribution is bounded to a given $V_{\max }$ value. This is not the case of the data we fit, i.e., we have no a-priori bound on the maximum volume size.

For the Grenoble inventory, these two techniques provide similar values, $b \sim 0.40$ (Table 1 ). The standard deviation of $b$ given by (3) is 0.06 , as estimated from the maximum likelihood method. These values are not sensitive to either a $V_{0}$ value increase above $40 \mathrm{~m}^{3}$ or a change in the analysed time period. Second, we use the $\chi^{2}$ test to validate the hypothesis that the observed volume distribution follows a power law distribution for volumes larger than $40 \mathrm{~m}^{3}$. The $\chi^{2}$ test compares an observed histogram to a histogram obtained by sampling the hypothesized distribution function [e.g. Press et al., 1992; Taylor, 1997]. The $\chi^{2}$ value measures a distance between these two histograms, as defined by,

$$
\chi^{2}=\sum_{i=1}^{k} \frac{\left(n_{i}-n_{i}^{*}\right)^{2}}{n_{i}^{*}},
$$

where $n_{i}$ is the observed number of events in the $i^{t h}$ bin, and $n_{i}^{*}$ is the expected number for the hypothesized distribution function. Equation (4) follows a socalled $\chi^{2}$ probability law, that allows evaluating the probability to overpass the $\chi^{2}$ value when the tested hypothesis is true. We use the reduced $\chi^{2}$ value [Press et al., 1992; Taylor, 1997], obtained by dividing the $\chi^{2}$ value by the number of degrees of freedom of the system, $n_{f}$ defined by,

$$
n_{f}=\text { (number of bins) }-c,
$$


where $c$ is the number of constraints applied for the $\chi^{2}$ test. For our application, $c=2$, with one constrain for the parameter of the law in the case of the power law, and one for the binning of the data in equiprobable classes [Press et al., 1992; Taylor, 1997]. A reduced $\chi^{2}>>1$ rejects the tested distribution as a possible description of the data.

Because the $\chi^{2}$ test requires Gaussian-distributed numbers of objects per bin, we have a trade off between the appropriate number of bins and the number of objects within each class. Using 11 bins, corresponding to 5 events per bin, we obtain a reduced $\chi^{2}$ value of 0.58 . The power-law distribution is thus accepted by the test with a $95 \%$ confidence value. We have tested different values of bin numbers between 5 and 18. The reduced $\chi^{2}$ value is always close to 1 , so that the power-law distribution is always accepted at the $95 \%$ confidence level. With the same type of analysis, we reject other distribution functions, such as the exponential, Weillbull and Gumbel distributions, to fit the Grenoble rock fall volume distribution in the same volume range.

\subsection{Yosemite inventory}

The rock fall volume distribution from the Yosemite inventory is built with 101 events that occurred in the 1915-1992 period (Figure 5). As for the Grenoble data set, we recover (i) a roughly linear pattern on a log-log plot for volumes larger $50 \mathrm{~m}^{3}$, (ii) a downward departure from the linear pattern for small volumes. For the 56 events of volume above $50 \mathrm{~m}^{3}$, we obtain $b=0.45$ from the maximum likelihood estimate of the cumulative volume distribution, with a standard deviation of 0.06 . Using the linear regression method we recover a similar $b$-value (Table 1 ). The $b$-value is not sensitive to changes in either the time period or the minimum volume above $50 \mathrm{~m}^{3}$.

Using 11 bins, corresponding to 5 events per bin, we obtain a reduced $\chi^{2}$ value of 0.72 . Therefore, the hypothesis that the rock fall volumes follow a power law is accepted at the $90 \%$ confidence level.

\subsection{World wide inventory}

The 142 events of the worldwide inventory range in size from $10^{4}$ to $10^{10} \mathrm{~m}^{3}$. The cumulative volume distribution shown in Figure 5 mimics the 2 previously analysed data sets. For the 54 events with a volume greater than $310^{7} \mathrm{~m}^{3}$, the observed distribution is well fitted by a power law distribution with $b=0.51$, in agreement with the other data sets ( Table
1). Using 10 bins, corresponding to 5 events per bin, we obtain a reduced $\chi^{2}$ value of 1.07 . Therefore, the hypothesis that the rock fall volumes follow a power law distribution above $10^{7} \mathrm{~m}^{3}$ is accepted at the $90 \%$ confidence level. Similar results are obtained when testing different bin numbers between 5 and 10 .

\section{Discussion}

\subsection{Synthesis of observed rock fall volume distributions}

The three originally analysed data sets display power law distributions of rock fall volumes, with similar power law exponents, i.e., in the range $0.4-0.6$ \pm 0.06 . The Yosemite and Grenoble cliffs are both steep cliffs made of strong rock, with the same cliff length. The geometries of the discontinuity patterns are different for the two cliffs. Sub-vertical fractures across gently dipping stratification characterize the Grenoble sedimentary cliffs, while exfoliation and sheeting of granitic domes are reported for Yosemite cliffs. This suggests that the geometry of the fracturing pattern does not influence the exponent of the power law distribution of rock fall volumes.

When taking together the three catalogs studied here, and the other results for rock falls on sub vertical cliffs, including natural rock slopes and road-cuts (Table 2), it suggests that rock fall volume distributions follow a power law distribution, with an average exponent of $0.5 \pm 0.2$ on a $10^{-3} \mathrm{~m}^{3}$ to $10^{10} \mathrm{~m}^{3}$ volume range. For the data sets listed on Table 2, even the largest events fit the power law distribution, without any cut-off. No finite size effect is thus observable. However, a possible finite size effect would come from the finite geometry of the rock slopes or cliffs. In particular, the height of cliff is a saturation length for the maximum available rock fall volumes on any given site.

Except for the seismically instrumented cliff on the Reunion island [Rousseau, 1999], all the reported rock fall volumes come from field evaluation (Table 2). As events are reported mainly when they induce damage to man-build or natural structures, the sampling is not uniform in the size domain. This sampling bias results in an underestimation of the number of small events. This bias is the best candidate to account for the re-currently observed deficit of small events relatively to the power law distribution for large volumes (Figure 5). There is no evidence that this bias may induce spurious power law behavior. However, it may lead to underestimate the exponent of the power law 
[e.g. Stark and Hovius, 2001; for tests on landslides].

As noted above, one study uses a continuous seismic monitoring to detect rock fall events and to size up rock fall volumes on a single, well defined cliff [Rousseau, 1999]. This sampling method and the measurement technique provide a catalog that is not affected by the same biases as the data previously described. The volume distribution derived from Rousseau's catalog also follows a power law distribution (Table 2). First, this result supports the hypothesis that the power-law derived from volumes estimated by field evaluations is not a measurement artifact. Second, it shows that a single cliff displays a power law volume distribution. It argues against the power law distribution to result from a geometrical effect, i.e., the power law does not result from an integration process over cliffs of different heights. Using the seismic monitoring technique, the exponent value of the power law is the largest reported value in the available catalogs for rock falls on sub-vertical cliffs (Table 2). It may be due to the assumption made to derive the rock fall volume from the seismic amplitude. Seismological volume estimates are supposed to scale with the amplitude of seismic signals [Rousseau, 1999], but this relation may be incorrect. Assuming that seismic amplitude scales with the square root of the rock fall volume, as also proposed by $A k i$ [personal communication, 2002], the exponent of rock fall volume distribution would be 0.5 instead of 1 , in agreement with other studies reported on Table 2. Comparisons of both seismological signals and rock falls volumes are necessary to validate the relation between volumes and amplitudes of seismic signals.

The power-law distribution has also been reported for mixed landslides (Table 3 and references therein). From our study, which focus on the rock fall volumes that occurred on sub vertical cliffs of stiff rock mass, we derive a $b$-value that is significantly smaller than the average exponent value, $1.2 \pm 0.3$, estimated from studies that mixed different types of landslides (Table 3 ). The exponents are volume exponents or surface exponents that were converted to volume using the rule of Hovius et al. [1997] when exponent value for volume are not available (Table 3 ). We use this conversion rule on the same type of catalogs (Table 3) than Hovius et al. study. This study hypothesizes that landslide length is proportional to thickness and width. Accordingly in absence of others tools, and for the robustness of comparison between catalogs, we choose to use the rule of[Hovius et al., 1997] de- tailed on Table (3). For all the cases listed on Table 3, reported landslides occur either on less steep topography or involve softer unconsolidated material than rockfalls reported in Table (2).

\subsection{Implication for rock fall hazard}

From the examples analysed in the previous sections, the hypothesis that the volume distributions of natural rock falls follow a power law distribution is accepted at a $90 \%$ confidence level. This distribution law provides the probability of occurrence of a given volume in a given time period on a given area, and has been used for hazard assessment by Hungr et al. [1999] for rock falls on man made slopes. Using the Grenoble data set as a test example, we can derive the occurrence rate of a given volume range by using the power law,

$$
N(V)=\frac{N_{0}}{T}\left(\frac{V}{V_{0}}\right)^{-b},
$$

$N(V)$ being the number of events per unit time with a volume larger than $V$ for a catalog of duration $T$. $N_{0}$ is the number of events with a volume larger than $V_{0}$. For the Grenoble inventory, $V_{0}=40 \mathrm{~m}^{3}, N_{0}=55$, the catalog duration we analysed is $T=60 \mathrm{yrs}$.

The return period of a rock fall of volume larger than or equal to $V$ is given by,

$$
t(V)=\frac{1}{N(V)} .
$$

Using (6) and (7) we obtain a 10 years return period for a $10^{4} \mathrm{~m}^{3}$ event, or an average of four $10^{5} \mathrm{~m}^{3}$ events within a century. The largest historical event reported in the last thousand years in the Grenoble area is the $1248 \mathrm{Mt}$ Granier rock avalanche of $5 \times 10^{8}$ $\mathrm{m}^{3}$. From the power law distribution based on the 1935-1995 data, we derive a return period of $870 \mathrm{yrs}$ for a Mt Granier size event. Therefore the largest observed event on a thousand-year period agrees with the return period for this volume. For this region the saturation volume for which the scaling law could change is roughly $\left(h_{\max }\right)^{3}, h_{\max }$ being the maximum cliff height, with $\left(h_{\max }\right)^{3} \sim 10^{9} \mathrm{~m}^{3}$ for Grenoble cliffs. This value is a first order estimate which includes the two levels of the Grenoble cliffs (Figure 1). Accordingly, the distribution must not be extrapolated to volumes larger than $10^{9} \mathrm{~m}^{3}$. Regarding the space domain, the presently limited number of data does not allow us to investigate spatial variations of rock fall occurrence rate. We can just provide the probability 
of occurrence for the whole studied area [Vengeon et al., 2001].

\subsection{Possible models for power law distributions of rockfall volumes}

There has not been yet any model which simulates specifically rock fall dynamics. One class of numerical models examines erosion; it can also apply to rock fall or landslide simulations [Hergarten and Neugebauer, 1998; Densmore et al., 1998]. The second class of models includes generic models that can apply to a large range of phenomena that exhibit scale invariant behavior, i.e., fragmentation and sand piles models.

4.3.1. Erosion type model. Densmore et al. [1998] proposed a numerical model that uses a slope stability criterion to simulate mechanics of hill slope failures. They obtain a power law distribution of volumes of mass movements. The exponent value of the simulated cumulative distribution varies as a function of the mechanical properties of the rock mass (cohesion and friction angle), from 1.2 for soft rock to 0.8 for hard rock. The authors suggest in their numerical simulation that a higher strength leads to steeper critical hill slope heights. Because in this model [Densmore et al., 1998; Champel et al., 2002] a higher strength corresponds to a steeper topography, simulations with stiff rock parameters may be related to rock fall circumstances on a sub vertical cliffs. Alternatively, we propose that other landslide types, which occurred on gentler slopes could be related to simulations with low strength materials that induce a lower exponent value for the power law distribution of volumes.

For mixed landslide types, the observed $b$-values (the exponents of the cumulative volume distributions), are in the range $0.7-1.3$, with an average value $b=1.2 \pm 0.3$ (Table 3). These values are significantly larger than those reported for rock falls on sub vertical cliffs. For rock fall settings (Table 2), i.e., stiff rock on sub vertical cliffs characterized by a friction angle close to $35-45^{\circ}$ [Hoek and Brown, 1980], the corresponding $b$-values range from 0.2 to 1 , with an average value of $0.5 \pm 0.2$. Therefore, the models of [Densmore et al., 1998; Champel et al., 2002] qualitatively predict the observed changes in exponents between mixed landslide types that occurred on gentle slope topography (Table 3) and rock falls on sub vertical cliffs (Table 2). According to this model, the change in exponent values is driven by changes in the mechanical properties (e.g. internal friction angle or cohesion) of the involved rock mass. Stiff rocks, with a higher friction angle, generate steeper topographic slopes and lower exponent values than softer rocks.

4.3.2. Fragmentation model. From a generic point of view, the power law distribution observed for rock fall volumes (Table 2) is also similar to the fragment size distribution reported during fragmentation experiments (e.g. Turcotte [1986] and reference therein). A power law distribution is admitted to characterize the distribution of fragments for a variety of rocks in laboratory experiments [e.g. Turcotte, 1986, and references therein]. Observed exponent values for cumulative volume distributions of fragments range from 0.5 to 1.2 , with 0.8 as an average value. A generic model of fragmentation generates a power distribution of fragments, with a $b$ exponent of the cumulative volume distribution defined by,

$$
b=\frac{\log (8 p)}{\log (8)},
$$

where $p$ is the probability of a given cell of size $l$ to break in 8 fragments of size $l / 2$. This breaking rule is scale invariant, i.e., each sub cell whatever its size has the same probability $p$ to break in 8 smaller cells [Turcotte, 1986]. Tuning of $p$ values allows recovering observed exponent values for rock fragmentation with $b<1$ for $p$ ranging from 0 to 1 . In this way, the power law distribution of rock fall volumes, with an exponent value ranging from 0.2 to 1 (Table 2), can be reproduced by this generic fragmentation model. Note that the observed exponents for rock falls, $0.5 \pm 0.2$, are in the same ranges of those reported for fragmentation.

It argues for the rock fall sizes to be possibly driven by the fragmentation process of the cliff, i.e., the preexisting discontinuity pattern. Accordingly, the rock mass fragment size should control the rock fall volume size, while neither cascade nor avalanche process should influence the rock fall volume distribution. This model can reproduce the observed distribution of rock fall volumes if the largest fragments are larger than the largest observed rock fall. Although the preexisting discontinuity pattern that controls the fragment size distribution is not extensively known for the studied cliffs, we observe that the number of rock blocks cut by discontinuities decreases rapidly when their size increases. It argues for possible large fragment sizes on our studied cliff.

4.3.3. Sand-pile type model. Another alternative to generate power law distributions is the conceptual sand-pile model of Bak et al. [1987]. For rock fall dynamics, the scale invariant rock fall distribu- 
tion could arise solely from the dynamic of mechanical processes without requiring any pre-existing scale invariant heterogeneity. Cellular automaton models simulate avalanches on a sand-pile. 3D numerical simulations yield an exponent value of 0.37 [Bak et al., $1987 ; 1989]$, close to those we report for natural rock falls. However this 3D model generates avalanches which take place in the bulk of a volume. Accordingly the mapping on the whole rock avalanches is difficult because most rock falls occur on the surface of cliff. The model that is usually interpreted in terms of sand pile is the $2 \mathrm{D}$ version of the model which yields a power law distribution with an exponent close to zero [Bak et al., 1987; 1989]. This later exponent value is further away from the observed rock fall size distribution. However, a variety of cellular automaton models can account for a change in exponent value when modifying the interaction rules or the loading rules of the generic sand pile model from Bak et al. [1987], e.g. Olami et al. [1992], Amaral and Lauritsen [1997]. Therefore these models could explain the $b$-value observed for the distribution of rock fall volumes. Without any other observational constrains on rockfall dynamics, we cannot decide which of the interactions rules or loading conditions of these different models are the more prone to capture the genuine rock falls dynamics.

Contrary to the fragmentation model, the sandpile model simulates a power law distribution of volumes that emerges solely from the dynamics without any input of quenched heterogeneity [e.g. Bak et al., 1987]. This model can be applied to any dynamic system characterized by a threshold dynamic, a stationary state, a slow exogeneous driving when compared to the energy released, and a power law distribution of energy released. Within this context, the driven forces for a rock fall dynamical system are both the slow tectonic uplift rate, the fluvial down cutting and the constant gravity force. They have characteristic time scales, which are well separated from the time life of one single rock fall event. On such a basis, the dynamics of rock fall process share the same properties as the one proposed for earthquakes, i.e., a slow driving relatively to the relaxation process and a power distribution of relaxed energy [Bak et al., 1989; Sornette and Sornette, 1989; Main, 1996; Grasso and Sornette, 1998, Vespignani and Zapperi, 1998]. As suggested for landslides of unconsolidated material on moderate slope by Hergarten and Neugebauer [1998], it argues for rock fall dynamics to be another example of out of equilibrium, scale free phenomena that could be generic to earth crust deformation processes.

As a tentative mapping of each class of models on rock fall dynamics from sub vertical cliffs and other landslide types respectively, we summarize the advantages and drawbacks of each model (Table (4)) - Possible applications of these models to reproduce landslide or rockfall cannot be sorted by using the exponent values of distribution. They come out from the specific hypothesis relevant to each model, i.e., erosion model, a sand-pile cellular automaton, fragmentation. Erosion models that introduce realistic mechanical properties of the cliff in the generic sandpile model appear to capture the basic patterns of the landslide and rock fall distributions [e.g. Densmore et al., 1998; Hergarten and Neugebauer, 1998]. If a fragmentation model is generically acceptable for rock falls on sub-vertical cliffs, including simulated exponent values, it is rejected as a model for the soft unconsolidated material involved in other landslide types. Similarly, the soil erosion model of Hergarten and Neugebauer [1998] is well suited to simulate landslides of layered soft material, but the exponent value and the layered model assumption itself reject the possibility for this model to reproduce rock falls dynamics of sub vertical cliffs. The erosion model from Densmore et al. [1998] is able to reproduce a change in exponent values that is observed when switching from events which originate on sub vertical cliffs of stiff rock to event occurring on gentle slopes of softer materials [Densmore et al., 1998; Champel et al., 2002].

\section{Conclusion}

We have analysed three rock fall data sets on sub vertical cliffs and we have shown that the rock fall volume distribution follows a power-law distribution for volumes ranging from $10^{2}$ to $10^{10} \mathrm{~m}^{3}$, with the exponents $b$ in the range [0.4-0.6] for the three catalogs. This exponent is also in agreement with previous studies of rock falls along road-cuts. We suggest two classes of models than can reproduce the power-law distribution of rock fall volumes.

First, the conceptual sand-pile model of [Bak et al., $1987 ; 1989$ ] can reproduce the avalanche-like behavior of the rock fall activity. Accordingly the power-law distribution of rock fall volumes is the avalanche like response to a slow loading rate, as driven by tectonic deformation and fluvial incision rates, when compared to the time scales of rock avalanches. This argues for the rock fall dynamics to be another class of out of 
equilibrium, scale free phenomena as suggested for a large variety of earth crust deformation processes. In this context, the power-law distribution of rock fall volumes would arise solely from the dynamic of the system, and would not be affected by the pre-existing heterogeneity pattern.

Second, the observed power law distribution of rock fall volumes is similar to the one reported for both fragmentation experiments and fragmentation models. This argues for the in-situ rock mass fragment sizes to possibly control the rock fall volumes. In this context, the rock fall volume distribution should be similar to the fragment size distribution, and neither cascade nor avalanche processes would influence the rock fall volume distribution.

When comparing our observations of rock falls on sub-vertical cliffs with different types of landslides, the exponent of the volume distribution is smaller for rock falls than for landslides involving unconsolidated material occurring on less steep slopes. It argues for the rock mass properties, which constrain the topography slope in numerical simulation [Densmore et al., 1998; Champel et al., 2002], to drive the change in exponent values for different landslide types and geomechanical settings.

Acknowledgments. We gratefully thank R. Couture, J.P. Requillard and G. Wieczorek, who made the data available for the three inventories we used in this study, world wide inventory, Grenoble area and Yosemite Valley respectively. Unpublished detailed comments on their own landslides and rock falls studies by K. Aki, B. Champel, N. Hovius, D. Keefer, J. Pelletier, N. Rousseau and C. Stark helped clarifying the final version of the paper. Reviews by A. Densmore, S. Hergarten and G. Wieczorek, improved the quality of the manuscript. J.M. Vengeon is acknowledged for his fruitful discussions and $\mathrm{R}$. Archuleta, A. McGarr and G. Wieczorek for their comments on an initial version of the manuscript. Detailed reviews by A. Densmore and S. Hergarten improved the quality of the manuscript.

\section{References}

Aki K., Maximum likelihood estimate of $\mathrm{b}$ in the formula $\log \mathrm{N}=\mathrm{a}-\mathrm{bM}$ and its confidence limits, Bull. Earthquakes Res. Institute, 43, 237-239, 1965.

Amaral, L.A.N., and K.B. Lauritsen, Universality classes for rice-pile models,Phys. Rev. E, 56, 231-234, 1997.

Bak, P., C. Tang, and K. Wiesenfeld, Self-organized criticality, Phys. Rev. A, 38, 364-374, 1987.

Bak. P. and C. Tang, Earthquakes as a self-organized critical phenomenon, J. Geophys. Res., 94, 15,635-15637,
1989.

Blodgett, T.A., B.L. Isacks, E.J. Fielding, J.G. Masek, and A.S. Warner, Erosion attributed to landslides in the Cordillera Real, Bolivia, EOS Trans. AGU, 17, Spring Meet. Suppl. S261, 1996.

Champel, B., P. Van der Beek, JL. Mugnier and P. Leturmy, Growth and lateral propagation of faultrelated folds in the Siwaliks of western Nepal: Rates, mechanisms and geomorphic signature, J. Geophys. Res. (in press), 2002.

Couture, R., Contribution aux aspects mécaniques et physiques des écroulements rocheux. Génie géologique, PhD Thesis, Saint-Foy, Quebec, U. Laval, 56-65, 1998.

Densmore, A., M. Ellis, and R. Anderson, Landsliding and the evolution of normal-fault- bounded mountains, $J$.. Geophys. Res., 103, 15,203-15,219, 1998.

Dixon T.H., Miller, M., Farina, F., Wang, H., and D. Johnson, Present-day motion in the Sierra Nevada block and some tectonic implications for the Basin and Range province, North America, Cordillera, Tectonics, 19, 1-24, 2000.

Fréchet, J., Sismicité du Sud-Est de la France et une nouvelle méthode de zonage sismique, Thèse 3ème cycle, Université de Grenoble, 159 pp, 1978.

Fuyii, Y., Frequency distribution of the landslides caused by heavy rain-fall, Seismological Society of Japan Journal, 22, 244-247, 1969.

Gardner, J., Rockfall : a geomorphic process in high mountain terrain, The Albertan Geographer, 6, 15-20, 1970.

Goguel, J., and A. Pachoud, Géologie et dynamique de l'écroulement du Mont Granier, dans le massif de la Chartreuse, en novembre 1248, Bulletin du BRGM III(1), 29-38, 1972.

Grasso, J.-R., F. Guyoton, J. Fréchet and J.F. Gamond, Triggered earthquakes as stress gauge: Implication for the uppercrust behavior in the Grenoble area, France, Pure Appl. Geophys., 139, 579-605, 1992.

Grasso, J.-R. and D. Sornette, Testing self organized criticality by induced seismicity, J. Geophys. Res., 103, 29,965-29,987, 1998.

Guillot, P. and R. Duband, La méthode du GRADEX pour le calcul de la probabilité de crues partir des pluies, IASH Publication, n84, 1967.

Gutenberg, B. and C. F. Richter, Seismicity of the Earth and Associated Phenomena, Princeton University press, Princeton, N.J., 1949.

Harp E.L. and R.L. Jibson, Inventory of landslide triggered by the 1994 Northridge California earthquake, U.S. Geol. Survey, Open-file report, 95-213 , 1995.

Hergarten, S., and J. Neugebauer, Self-organized criticality in a landslide model, Geophys. Res. Lett., 25, 801804, 1998.

Hoek, E., and E.T. Brown, Underground excavations in rock, Institution of Mining and Metallurgy, London, 1980 . 
Hovius, N., C.P. Stark, and P.A. Allen, Sediment flux from a mountain belt derived by landslide mapping, Geology 25, 231-234, 1997.

Huber, N. K., The geologic story of Yosemite national Park, U.S. Geological Survey Bulletin, 1595, pp. 59, 1987.

Hungr, O., S.G. Evans, and J. Hazzard, Magnitude and frequency of rock falls along the main transportation corridors of southwestern British Columbia, Canadian Geotechnical Journal, 36, 224-238, 1999.

Keefer, D.K., Rock avalanches caused by earthquakes:Source characteristics, Science, 223, 1288-1290, 1984.

Keefer, D.K., Earthquake-indiced landslides and their effects on alluvial fans, J. Sedimentary Research, 69.1, 84-104, 1999.

Main, I., Statistical Physics, seismographs and seismic hazard, Reviews of Geophysics, 34, 433-462, 1996.

Malamud, B.D. and D.L. Turcotte, Self organized criticality applied to natural hazards, Natural Hazards, 20, 93-116, 1999

Martinod J., F. Jouanne, J. Taverna, G. Menard, J.F. Gamond, X. Darmantrail, J.C. Notter, and C. Basile, Present day deformation of the Dauphine (SE France) Alpine and Subalpine massifs, Geophys. J. Int., 127, 189- 200, 1996.

Nielsen, T.H., J.A., Bartow, Jr., V.A., Frizell, and J.D., Sims, Preliminary photointerpretation maps of landslides and other superficial deposits of 567 -minutes quadrangle in the southeastern San Francisco Bay region, Alameda, Contra costa and Santa Clara countries, California, U.S. Geol Sur. Open-file report 75-0277, 1975.

Noever, D. A., Himalayan sandpiles, Phys. Rev. E, 47, 724-725, 1993.

Olami, Z., H.J.S. Feder, and K. Christensen, Self-Organized Criticality in a continuous non- conservative cellular automaton modeling earthquakes, Phys. Rev. Lett., 68, 1244-1247, 1992.

Pelletier, J.D., B.D. Malamud, T.A. Blodgett and D.L. Turcotte, Scale invariance of soil moisture variability and its implications for the frequency size distribution of landslides, Eng. Geol., 48, 255-268, 1997.

Pickering, G., J. M. Bull, and D. J. Sanderson, Sampling power-law distribution, Tectonophysics, 248, 120, 1995.

Press, W.H., S.A. Teukolsky, W.T. Vettering and B.P. Flannery, Numerical recipes in C, Cambridge Univeristy Press, pp. 994, 1992.

Rousseau, N., Study of seismic signals associated with rockfalls at 2 sites on the Reunion island (Mahavel Cascade and Souffriére cavity), PhD thesis, IPG Paris, 1999.

RTM, Isére, Inventaire des mouvements rocheux, Secteur de l'Y grenoblois. Grenoble, France, Service de Restauration des Terrains en Montagne de l'Isére, 1996.

Sornette A. and D. Sornette, Self organized criticality and earthquakes, Europhys. Lett., 9, 197- 202, 1989.

Stark, C.P. and N. Hovius, The characterization of landslides size distributions, Geophys. Res. Lett., 28, 10911094, 2001.

Sugai, T., H. Ohmori, and M. Hirano, Rock control on magnitude-frequency distribution of landslides, Transactions of Japanese Geomorphological Union, 15, 233351, 1994.

Taylor, J. R., An introduction to error analysis, University science Books, Sausalito, California, 2nd ed., pp 327, 1997.

Turcotte, D., Fractals and Fragmentation, J. Geophys. Res, 91, 1921-1926, 1986.

U.S. Water Resources Council, Guidelines for determining flood flow frequency, Bulletin 17B: Hydrology subcommittee, Office of Water Data Coordination, U.S. Geological Survey, Reston, VA, 182p, 1982.

Varnes D. J., Slope movements: types and processes. In: Landslide analysis and control. Edited by Schuster R. L. \& Krizek R. J., Transp. Research Board, Special Report 176, 11-33, Nat. Ac. Sci., Washington, 1978.

Vengeon, J.M., D. Hantz, and C. Dussauge, Predictabilité des éboulements rocheux: approche probabiliste par combinaison d'études historiques et géomécaniques, $R e$ vue Francaise Géotechnique, 95-96, 143-153, 2001.

Vespignani A. and S. Zapperi, How self organized criticality works: a unified mean field picture, Phys. Rev. E., 57, 6345-6362,1998.

Wesnousky, S., C. Scholz, K. Shimazaki, and T. Matsuda, Earthquake frequency distribution and the mechanics of faulting, J. Geophys. Res., 88, 9331-9340, 1983.

Wesnousky, S., C. Scholz, K. Shimazaki, and T. Matsuda, Integration of geological and seismological data for the analysis of seismic hazard: A case study of Japan, Bull. Seis. Soc. Am., 74, 687-708, 1984.

Wieczorek, G.F., J.B. Snyder, C.S. Alger and K.A. Isaacson, Yosemite historical rockfall inventory, U.S Geological Survey, Open File Report 92-387, pp.38, 1992.

Wieczorek, G.F., S.P. Nishenko, and D.J. Varnes, Analysis of rock falls in the Yosemite Valley, California, Proceedings of 35th U.S. Symposium on Rock Mechanics, Daemen, J.J., and Schultz, R.A., eds., A.A. Balkema, p 85-89, 1995.

Carine Dussauge, Laboratoire Interdisciplinaire de Géologie et de mécanique, Université Joseph Fourier, BP 53X, 38041 Grenoble Cedex, France. email: carine.dussauge@ujf-grenoble.fr

Agnès Helmstetter, Laboratoire de Géophysique Interne et Tectonophysique, Observatoire de Grenoble, Université Joseph Fourier, BP 53X, 38041 Grenoble Cedex, France. (e-mail: ahelmste@obs.ujf-grenoble.fr) Jean-Robert Grasso, Laboratoire de Géophysique Interne et Tectonophysique, Observatoire de Grenoble, Université Joseph Fourier, BP 53X, 38041 Grenoble Cedex, France. (e-mail:Jean-Robert.Grasso@obs.ujf- 
grenoble.fr)

This preprint was prepared with AGU's LATEX macros v5.01. File REVROCK4 formatted December 24, 2002. 

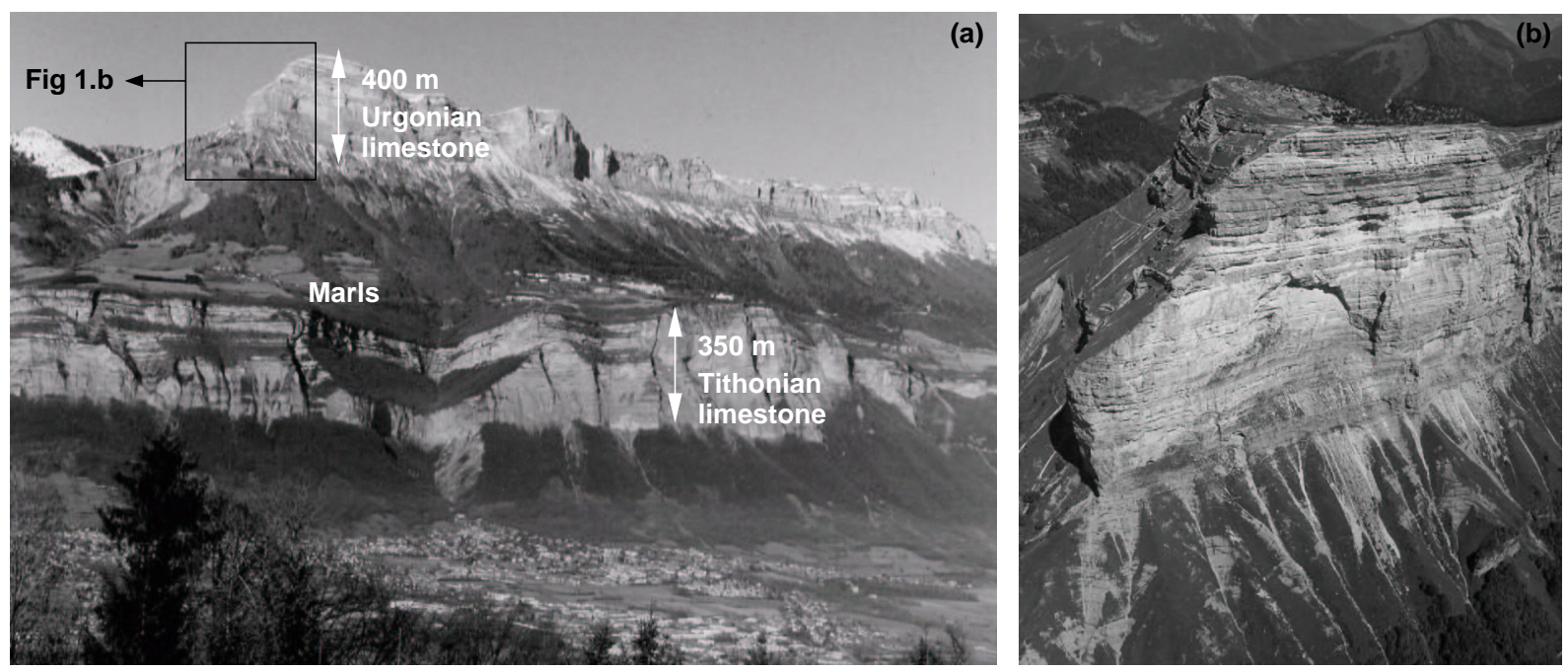

Figure 1. East face of the Chartreuse massif, Grenoble, France. (a) Subvertical calcareous cliffs are separated into two levels; the intermediate, less steep, slope is associated to marly levels. The maximum height of each level is $350-400 \mathrm{~m}$ and the total length of cliffs is $120 \mathrm{~km}$. Note the sub-urban area of Grenoble at the bottom of the cliffs. The photograph, by J.M. Vengeon, is roughly $5 \%$ of the total area covered by the Grenoble rock fall inventory [RTM, 1996]. (b) Geometry of the fracture pattern, as detailled from top of the cliff on (a). It is roughly characterized by a subhorizontal bedding and subvertical orthogonal joints; the small vertical joint are not visible at the scale of figure $1 \mathrm{~b}$. 

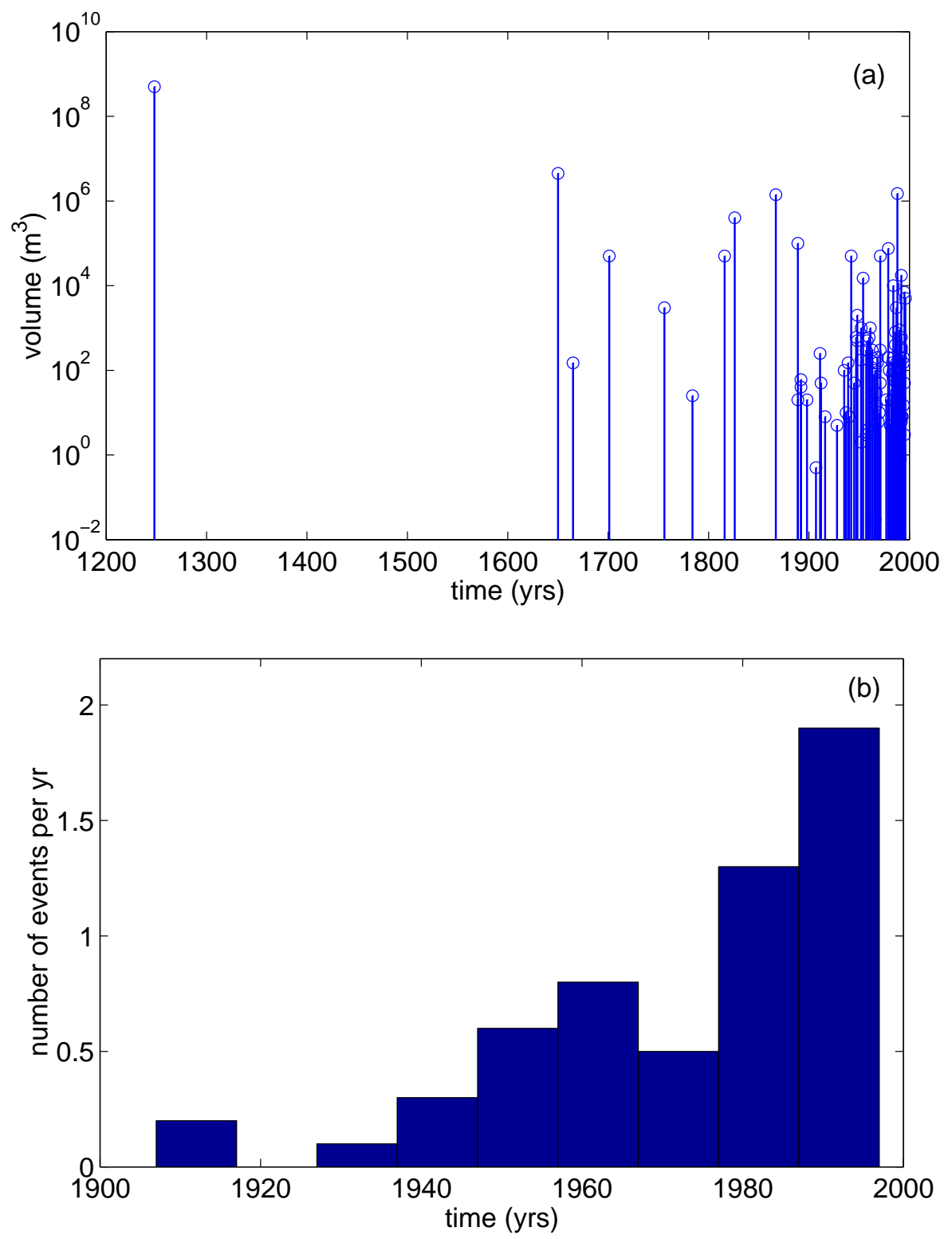

Figure 2. Occurrence rate for rock falls for Grenoble area, RTM inventory [1996]. a) volumes and time of occurrence in the 1200-1995 period. b) Occurrence rate in the 1935-1995 period for volume larger than $50 \mathrm{~m}^{3}$. Due to the non uniform temporal and volume samplings, the studied catalog is restricted to the 1935-1995 period, involving 87 events with volumes ranging from $10^{-2}$ to $10^{6} \mathrm{~m}^{3}$. 

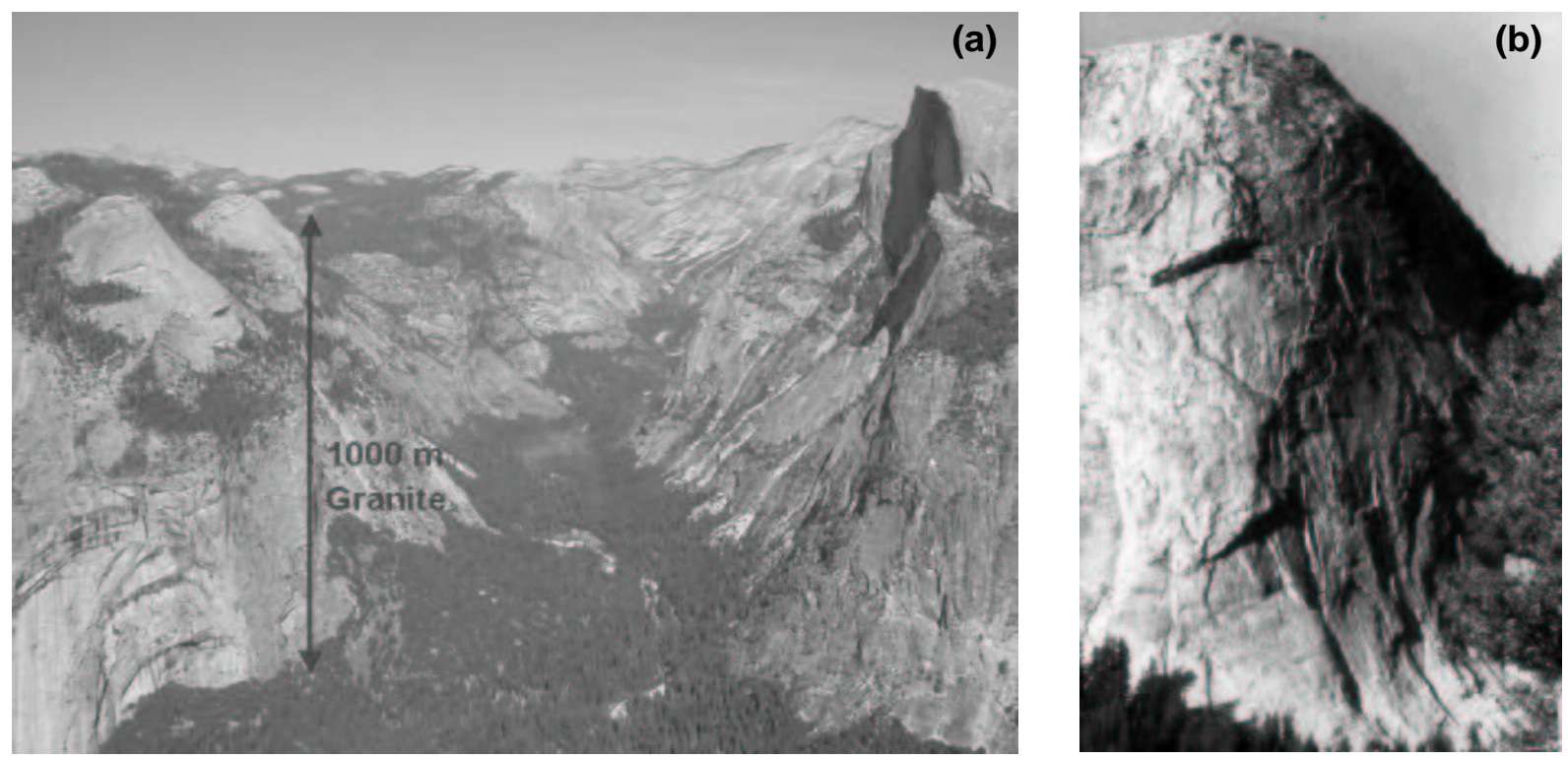

Figure 3. Cliffs surrounding the Yosemite Valley, California Sierra. (a) Subvertical granitic cliffs, maximum height 800-1000 m, total length $100 \mathrm{~km}$; photograph by G. Wieczorek. (b) Detailed view of the Fairview dome: the fracture pattern is roughly characterized by a sheeting process giving joints parallel to the topography, and spaced subvertical joints; photograph by J.R. Grasso. 

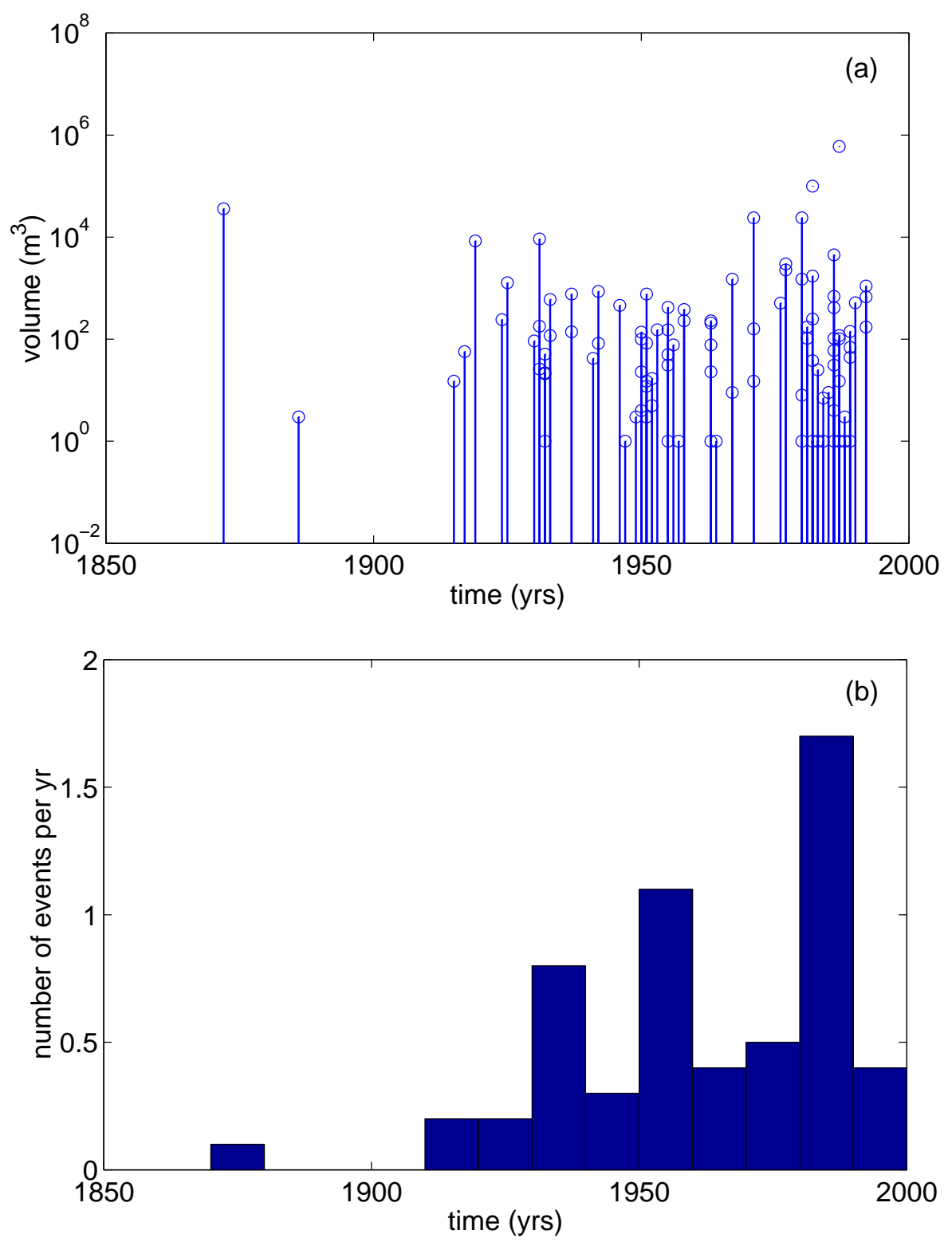

Figure 4. Occurrence rate for rock falls from the Yosemite Valley data set [Wieczorek, 1992]. a) Volume and occurrence for the 1850-1992 period. b) Occurrence rate in the the 1915-1992 period for volume larger than $50 \mathrm{~m}^{3}$. Due to the non uniform temporal sampling shown on the 1850-1992 period, the time window selected for the study is 1915-1995, involving 101 events with volumes ranging from 1 to $10^{6} \mathrm{~m}^{3}$. 

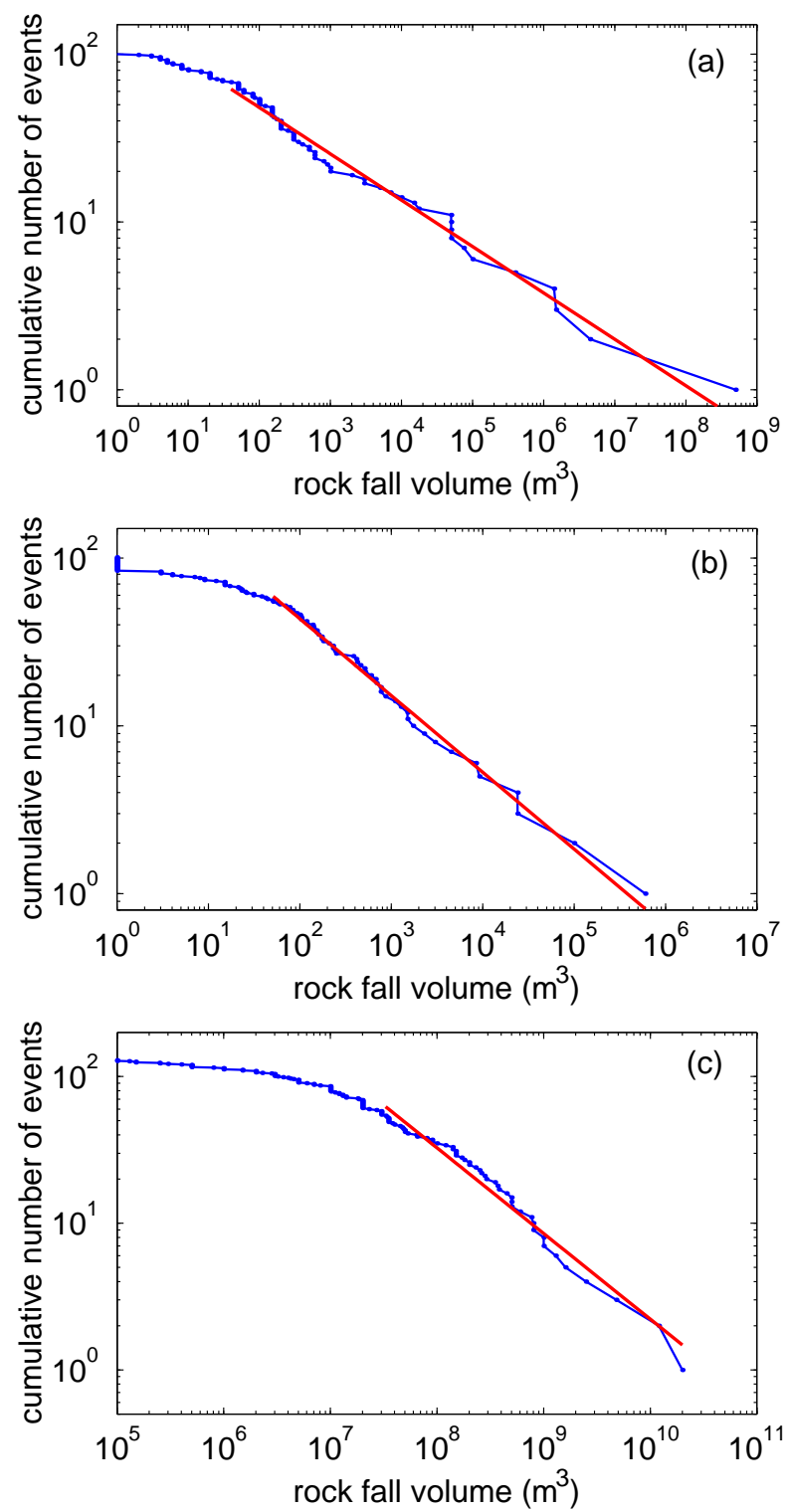

Figure 5. Cumulative volume distributions for rock falls. For each plot, the straight line is a fit by a power law for volumes larger than $V_{0}$, estimated by linear regression. The exponent values and the $\chi^{2}$ values are given in Table (1), see text for details. (a) Grenoble area; (b) Yosemite Valley; (c) World wide inventory. 
Table 1. Characteristics of Rock Fall Volume Distributions for the Three Studied Data Sets: $b_{l r}$ is the linear regression estimate of $b$-value; $b_{m l}$, the maximum likelihood estimate of $b$-value; $V_{o b s}$, the range of observed volume values; $V_{0}$, the value of minimum volume used for power law fit; $\chi_{r}^{2}$, the reduced $\chi^{2}$ value

\begin{tabular}{lllclllll}
\hline \multicolumn{1}{c}{ Site } & Time Window & $N_{\text {events }}$ & $V_{\text {obs }} \mathrm{m}^{3}$ & $V_{0} \mathrm{~m}^{3}$ & $N_{f i t}$ & $b_{l r}$ & $b_{m l}$ & $\chi_{r}^{2}$ \\
\hline Grenoble, France & $1935-1995$ & 87 & $10^{-2}-10^{6}$ & 40 & 55 & 0.40 & $0.41 \pm 0.06$ & 0.58 \\
Yosemite, USA & $1915-1992$ & 101 & $1-10^{6}$ & 50 & 55 & 0.46 & $0.45 \pm 0.06$ & 0.72 \\
Worldwide & $10000 \mathrm{yrs}$ & 142 & $10^{3}-2 \times 10^{10}$ & $3.1 \times 10^{7}$ & 54 & 0.58 & $0.51 \pm 0.07$ & 1.07 \\
& & & & & & & & \\
\hline
\end{tabular}


Table 2. Characteristics of Rock Fall Volume Distributions on subvertical cliffs

\begin{tabular}{|c|c|c|c|c|c|c|c|}
\hline Site & Geological Setting & Duration & $N$ & $V_{o b s} \mathrm{~m}^{3}$ & $\mathrm{~V}_{0} \mathrm{~m}^{3}$ & $b^{a}$ & Ref \\
\hline $\begin{array}{l}\text { Grenoble, } \\
\text { French Alps }\end{array}$ & $\begin{array}{l}\text { Calcareous } \\
\text { Cliffs }\end{array}$ & $1935-1995$ & 87 & $10^{-2}-10^{6}$ & 40 & 0.41 & $6^{1}$ \\
\hline $\begin{array}{l}\text { Yosemite, } \\
\text { California }\end{array}$ & $\begin{array}{l}\text { Granitic } \\
\text { Cliffs }\end{array}$ & 1915-1992 & 101 & $1-10^{6}$ & 50 & 0.45 & $6^{2}$ \\
\hline Worldwide & $\begin{array}{l}\text { Undifferentiated } \\
\text { Cliffs }\end{array}$ & $10000 \mathrm{yrs}$ & 142 & $10^{3}-2 \times 10^{10}$ & $3 \times 10^{7}$ & 0.51 & $6^{3}$ \\
\hline $\begin{array}{l}\text { Reunion Island, } \\
\text { Indian Ocean }\end{array}$ & $\begin{array}{l}\text { Basaltic } \\
\text { Cliffs }\end{array}$ & $\begin{array}{l}\text { May-Aug. } \\
1998\end{array}$ & 370 & $\leq 9 \times 10^{6}$ & $b 1$ & $0.5^{b}-1^{b}$ & 1,5 \\
\hline $\begin{array}{l}\text { Himalaya, } \\
\text { India }\end{array}$ & Road cuts & $\cdots$ & 200 & $10^{-6}-10^{6}$ & 10 & 0.19 & 4 \\
\hline $\begin{array}{l}\text { Himalaya, } \\
\text { India }\end{array}$ & Road cuts & $\cdots$ & 200 & $10^{-2}-10^{7}$ & 10 & 0.23 & 4 \\
\hline $\begin{array}{l}\text { Alberta, } \\
\text { Canada }\end{array}$ & $\begin{array}{l}\text { Calcareous and } \\
\text { quartzitic Cliffs }\end{array}$ & 2 summers & 409 & $10^{-6}-10$ & $10^{-2}$ & 0.72 & 2 \\
\hline $\begin{array}{l}\text { B. Columbia, } \\
\text { Canada }\end{array}$ & $\begin{array}{l}\text { Massive felsic rock, } \\
\text { road cuts }{ }^{c 1}\end{array}$ & $30 \mathrm{yrs}$ & 389 & $10^{-2}-10^{7}$ & $10^{-2}$ & 0.43 & $3^{c 1}$ \\
\hline $\begin{array}{l}\text { B.Columbia, } \\
\text { Canada }\end{array}$ & $\begin{array}{l}\text { Massive felsic rock, } \\
\text { road cuts }{ }^{c 2}\end{array}$ & $13 \mathrm{yrs}$ & 123 & $10^{-2}-10^{7}$ & 1 & 0.40 & $3^{c 2}$ \\
\hline $\begin{array}{l}\text { B.Columbia, } \\
\text { Canada }\end{array}$ & $\begin{array}{l}\text { Jointed metamorphic, } \\
\text { rock, road } \text { cuts }^{c 3}\end{array}$ & $\cdots$ & 64 & $10^{-2}-10^{7}$ & 1 & 0.70 & $3^{c 3}$ \\
\hline $\begin{array}{l}\text { B.Columbia, } \\
\text { Canada }\end{array}$ & $\begin{array}{l}\text { Jointed metamorphic, } \\
\text { rock, road cuts }\end{array}$ & $22 \mathrm{yrs}$ & 122 & $10^{-2}-10^{7}$ & 1 & 0.65 & $3^{c 4}$ \\
\hline
\end{tabular}

Reference: 1, Aki personal communication [2002]; 2, Gardner [1970]; 3, Hungr et al. [1999]; 4, Noever [1993]; 5, Rousseau [1999]; 6, (This study), data from ${ }^{1}$ RTM [1996]; ${ }^{2}$ Wiezoreck [1992]; ${ }^{3}$ Couture [1998].

${ }^{a}$ Exponent for cumulative volume distribution.

${ }^{b}$ Exponent deduced from amplitude of seismic signals using different models, see text for details; ${ }^{b 1}$ accordingly the absolute volumes are dependent of the exponent values for each of the seismic model.

${ }^{c}$ Studies on different locations in the same area: ${ }^{c 1}$ Highway 99 , bands A and B, ${ }^{c 2} \mathrm{BCR},{ }^{c 3}$ Highway $1,{ }^{c 4} \mathrm{CP}$. 
Table 3. Characteristics of Volume Distributions for mixed landslide types

\begin{tabular}{|c|c|c|c|c|c|}
\hline Site & Geological Setting & $\mathrm{N}$ & $\mathrm{V} \mathrm{m}^{3}$ & $b$ & Ref \\
\hline $\begin{array}{l}\text { Southern Alps, } \\
\text { New Zealand }\end{array}$ & $35^{\circ}$ mean slope & 4984 & $10^{6}-3 \times 10^{7}$ & 0.8 & 4 \\
\hline Japan, & & 650 & $3 \times 10^{4}-3 \times 10^{7}$ & 0.66 & 4 \\
\hline $\begin{array}{r}\text { Akaishi Mountains, } \\
\text { Japan }\end{array}$ & $\begin{array}{l}\text { non vertical } \\
\text { slope }\end{array}$ & 3243 & $10^{4}-10^{6}$ & 0.64 & 4 \\
\hline $\begin{array}{r}\text { Akaishi Mountains, } \\
\text { Japan }\end{array}$ & $\begin{array}{l}\text { non vertical } \\
\text { slope }\end{array}$ & 3243 & $10^{4}-10^{6}$ & $1.25^{c}$ & 5,7 \\
\hline $\begin{array}{c}\text { Challana Valley, } \\
\text { Bolivian Andes }\end{array}$ & $\begin{array}{l}\text { non vertical } \\
\text { slope }\end{array}$ & 1130 & $\cdots$ & $1.07^{c}$ & 5,7 \\
\hline $\begin{array}{l}\text { Challana Valley, } \\
\text { Bolivian Andes }\end{array}$ & $\begin{array}{l}\text { non vertical } \\
\text { slope }\end{array}$ & 1130 & $\cdots$ & $1.25^{c}$ & 5 \\
\hline $\begin{array}{l}\text { Northridge, California, } \\
\text { earthquake triggered }\end{array}$ & $\begin{array}{l}\text { uncons. earth } \\
\& \text { debris materials }\end{array}$ & 11000 & $\cdots$ & $0.86^{c}$ & 5 \\
\hline $\begin{array}{r}\text { Northridge, California } \\
\text { earthquake triggered }\end{array}$ & $\begin{array}{l}\text { uncons. earth } \\
\& \text { debris materials }\end{array}$ & 11000 & $\cdots$ & $1.07^{c}$ & 7 \\
\hline $\begin{array}{r}\text { Eden Canyon } \\
\text { USA }\end{array}$ & $\begin{array}{l}10-35^{\circ} \text { slope, uncons. } \\
\text { materials }\end{array}$ & 709 & $\cdots$ & $1.4^{c}$ & 5 \\
\hline
\end{tabular}

Reference: 1, Blodgett et al., [1996]; 2, Fuyii, [1969]; 3, Harp and Jibson,[1995]; 4, Hovius et al., [1997]; 5, Malamud and Turcotte, [1999]; 6, Nielsen et al., [1975]; 7, Pelletier et al., [1997]; 8, Sugai et al, [1994];

All the exponent values are for the cumulative volume distributions. ${ }^{c}$ The last five rows correspond to catalogs of landslides on medium slope that provide only surface estimate mesured by aerila photography. Accordingly, the range of volume used for these studies is not given in the forth column For these catalogs, volume exponents are derived from surface size distributions according to the Hovius et al., [1997] conversion rule, assuming landslide length is proportional to thickness and width. It implies Area Volume $e^{2 / 3}$. Then starting with, $N(V) \sim V^{-b}, N(V)$ being the number of events with a volume larger than $V$, implies $N(A) \sim A^{-2 b / 3}$ for cumulative areas. 
Table 4. Possible Conceptual Models for Rock Fall and Landslide Distributions

\begin{tabular}{|c|c|c|c|c|c|}
\hline Generic type & Ref & Loading & Breaking rules & $b$-value ${ }^{a}$ & Application \\
\hline $\begin{array}{l}\text { Landslide Model } \\
\text { of Rock erosion }\end{array}$ & $\begin{array}{l}2 \\
2\end{array}$ & $\begin{array}{l}\text { Tectonic uplift, } \\
\text { gravity, fluvial cut }\end{array}$ & $\begin{array}{c}\text { Slope stability }= \\
\mathrm{f}(\text { friction, cohesion })\end{array}$ & $\begin{array}{l}0.8 \\
1.2\end{array}$ & $\begin{array}{l}\text { rock fall } \\
\text { landslide }\end{array}$ \\
\hline $\begin{array}{l}\text { Landslide Model } \\
\text { of layered Soil }\end{array}$ & 3 & $\begin{array}{c}\text { Tectonic uplift } \\
\text { gravity, fluvial cut. }\end{array}$ & $\begin{array}{l}\text { Slope Gradient = } \\
\mathrm{f}(\text { layer thickness })\end{array}$ & 0.70 & landslide \\
\hline $\begin{array}{l}\text { Sand-pile } \\
\text { Cellular-Automata }\end{array}$ & 1 & $\begin{array}{l}\text { Additional sand } \\
\text { grains }\end{array}$ & $\begin{array}{l}\text { Critical slope } \\
\text { angle }\end{array}$ & $\begin{array}{l}\sim 0,(2 \mathrm{D}) \\
0.4,(3 \mathrm{D})\end{array}$ & $\begin{array}{c}\text { landslide } \\
\text { and rockf all }\end{array}$ \\
\hline Fragmentation & 4 & no loading & $\begin{array}{c}\text { Fragmentation } \\
\text { probability law }(p)\end{array}$ & $\begin{array}{l}<1 \\
f(p)\end{array}$ & rock fall \\
\hline
\end{tabular}

References: 1, Bak et al., [1987]; 2, Densmore et al., [1998]; 3, Hergarten and Neugebauer [1998]; 4, Turcotte., [1986]. ${ }^{a}$ All the exponent values are exponents of cumulative volume distributions. 